\title{
Proceeding
}

Supplementary Issue: Summer Conferences of Sports Science. Costa Blanca Sports Science Events, 20-21 September 2019. Alicante, Spain.

\section{The effect of lactate threshold training on improving the functionality of the lungs}

\author{
ZAYDON J. MOHAMMED 14 , HUSSAIN M. SADOWN², MOHAMMED H. HUMAIDI² \\ ${ }^{1}$ Faculty of Physical Education and Sports Sciences, Baghdad University, Baghdad, Iraq \\ ${ }^{2}$ Faculty of Physical Education and Sports Sciences, Maysan University, Maysan, Iraq
}

\begin{abstract}
The general and specific preparation process for mid-distance runners, physically and functionally ability is by given enough aerobic and anaerobic energy by various percentage according to the activity requirement. As a result, the longer distance needs a higher aerobic energy and vice versa. For example, $800 \mathrm{~m}$ sprinting is the most difficult from the point of view of coaching, as the runner needs to improve his energy system and defined the lactate system. This study is to prepare such type of Lactate Threshold Training (LTT) for young runners to achieve $800 \mathrm{~m}$ activity. The identification of the effect of (LTT) in improving the lungs functionality variables is the runner achievement key factor. Experimental methodology was used to satisfy the requirement of this study as it is the most suitable methodology for this type of studies. 14 Young runners within the age of (16-18) years old from elite teams were selected. The 14 runners divided into two groups in a comprehensive manner based on 7 samples in each monitored and experimental groups. The conclusion is conducted to establish a technical LTT implemented by the experimental group and shows a significant improvement in attaining $800 \mathrm{~m}$ sprinting. Some of lungs functionality variables were enhanced to the significance level. Those lungs functionalities are; dynamic lung volume, pulmonary function tests and maximum lung tidal volume. Keywords: Lactate; Training; Lungs.
\end{abstract}

\section{Cite this article as:}

Mohammed, Z.J., Sadown, H.M. \& Humaidi, M.H. (2019). The effect of lactate threshold training on improving the functionality of the lungs. Journal of Human Sport and Exercise, 14(5proc), S1876S1883. doi:https://doi.org/10.14198/jhse.2019.14.Proc5.07

Corresponding author. Faculty of Physical Education and Sport Science, University of Baghdad, Baghdad, Iraq.

E-mail: dr.ghafarsaeedissa@gmail.com

Supplementary Issue: Summer Conferences of Sports Science. Costa Blanca Sports Science Events, 20-21 September 2019. Alicante, Spain.

JOURNAL OF HUMAN SPORT \& EXERCISE ISSN 1988-5202

(c) Faculty of Education. University of Alicante

doi:10.14198/jhse.2019.14.Proc5.07 


\section{INTRODUCTION}

Physical and functional body organs preparation is important to enhance the athletic levels of achievements. Level of achievements reached by sport champions is incredible because of physical science perfections, sport training and its psychology. Today training is focusing on the energy production system and the functional variable due. It is clearly approved that developing the aerobic and anaerobic runner abilities is developing the physical, skills and achievements as a result. As per of this fact, training program should be high effective on the energy system of the ethical activity.

Athletics are totally depending on the Fitness elements which is reflecting directly on the achievement level. The functional physiological aspects are improved by improving the Systemic circulation and human respiratory system, as each ethical activity has such characteristics and requirements. $800 \mathrm{~m}$ sprinting race is an Olympic middle-distance sprinting's most interesting ethical activity. The use of the right scientific principles and the typical training to make a good progress in runner physical ability is directly depend on aerobic endurance in $800 \mathrm{~m}$ race. Therefore, this study is focusing on Lactate threshold training programs to develop the functional variables of $800 \mathrm{~m}$ race runner lungs. There are two types of physical skills must be developed, which a general and specific functionality and both are giving enough power of aerobic and anaerobic energies within different percentages due to the needs of such activity. As the race distance is increasing as there will be a need of higher aerobic energy and when the distance is short the training is likely diverting into anaerobic energy.

The researchers involved in this study are Iraqi coaches and member of Iraqi Central Athletics Federation. By following up the Iraqi Athletic Olympic with the collection of several databases in this field, we believe that there is not enough training and coaching attention to cover the physiological aspect. This is affecting the runner skill level and it can be identified clearly in the last few meters of the race where the performance is dropped to be very low. An academic study is required to determine a new lactate threshold training strategy and to develop the lungs functional variables for the young $800 \mathrm{~m}$ runners. We are aiming to be able to treat the shortage in this manner and helping the runners and the coaches by provide them with the typical sport physiological knowledge.

We are looking toward our objectives by preparing an effective lactate training programs and to determine the development factors in lungs functional variables.

\section{METHODOLOGY}

\section{Participants}

Experimental methodology is the better method to approach the objectives of this study and therefore, the sampling was selected from the young elite team within the age of 16-18 years old. 14 samples were used based on 2 groups (monitored and experimental), 7 runners on each group with an implementation of objectivity principles of work by finding the homogeneity and equivalence between the 2 groups from the point of view of body measurements (tall, mass or weight, training age and time). As well as, lugs functional variables and statistical data analysis.

The pattern used to improve the lactate threshold training is shown in table 1. This pattern was selected carefully after long period of investigation and expert's discussion. 
Table 2 is showing the homogeneity and equivalence of the 2 study groups, the foundations and the standards used to complete the investigation. The table shows the statistical analysis of the principle measurements and confirming high homogeneity.

Table 1. Sample of lactate threshold training pattern used in this study.

\begin{tabular}{|c|c|c|c|c|c|c|c|}
\hline \multirow{2}{*}{ 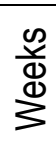 } & \multirow[b]{2}{*}{ Training Uni } & \multirow[b]{2}{*}{ Exercises } & \multirow{2}{*}{ 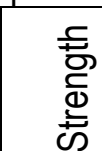 } & \multicolumn{2}{|c|}{ Capacity } & \multicolumn{2}{|c|}{ Rest/ Heartbeat return } \\
\hline & & & & Iteration & Group & $\begin{array}{l}\text { Iterations } \\
\text { intervals }\end{array}$ & \begin{tabular}{|l} 
Group \\
intervals
\end{tabular} \\
\hline \multirow{6}{*}{\begin{tabular}{l}
$\bar{y}$ \\
d \\
\} & \multirow{2}{*}{ First } & \multirow{2}{*}{\begin{tabular}{|l}
350 sprinting \\
400 sprinting
\end{tabular}} & \multirow{2}{*}{$80 \%$} & & $3 \times 3$ & $110-120$ & $3 \mathrm{~min}$ \\
\hline & & & & & 6 & - & $120-130$ \\
\hline & \multirow{2}{*}{ Second } & \multirow{2}{*}{$\begin{array}{l}400 \text { sprinting } \\
500 \text { sprinting }\end{array}$} & \multirow{2}{*}{$90 \%$} & & $3 \times 3$ & $120-130$ & $4 \min$ \\
\hline & & & & & 6 & - & $120-130$ \\
\hline & \multirow{2}{*}{ Third } & \multirow{2}{*}{\begin{tabular}{|l|}
600 sprinting \\
800 printing
\end{tabular}} & \multirow{2}{*}{$80 \%$} & & 4 & - & $120-130$ \\
\hline & & & & & 6 & - & $120-130$ \\
\hline \multirow{6}{*}{$\begin{array}{l}N \\
\text { d } \\
\stackrel{\Phi}{3}\end{array}$} & \multirow{2}{*}{ Forth } & 700 sprinting & \multirow{2}{*}{$80 \%$} & & 4 & - & $120-130$ \\
\hline & & 900 sprinting & & & 6 & - & $120-130$ \\
\hline & \multirow{2}{*}{ Fifth } & 700 sprinting & \multirow{2}{*}{$90 \%$} & 6 & & $100-110$ & 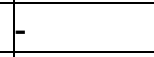 \\
\hline & & 600 sprinting & & & 4 & - & $5 \mathrm{~min}$ \\
\hline & \multirow{2}{*}{ Sixth } & 800 sprinting & \multirow{2}{*}{$85 \%$} & 6 & & $120-130$ & f \\
\hline & & 600 sprinting & & & 4 & - & $120-130$ \\
\hline
\end{tabular}}
\end{tabular}

Table 2. Sampling homogeneity.

\begin{tabular}{|c|c|c|c|c|c|}
\hline \multirow[b]{2}{*}{ Variables } & \multirow[b]{2}{*}{$\begin{array}{l}\text { Measuring } \\
\text { Unit }\end{array}$} & \multicolumn{2}{|c|}{ Levene's test } & \multirow[b]{2}{*}{$\begin{array}{l}\text { Level of } \\
\text { significance }\end{array}$} & \multirow[b]{2}{*}{ Homogeneity } \\
\hline & & Calculated & $\begin{array}{l}\text { Standard } \\
\text { Deviation }\end{array}$ & & \\
\hline Age & year & 1.324 & 0.322 & Not significant & Homo \\
\hline Training age & year & 0.301 & 0.429 & Not significant & Homo \\
\hline Tall & $\mathrm{kg}$ & 0.077 & 0.871 & Not significant & Homo \\
\hline Weight & $\mathrm{cm}$ & 1.301 & 0.320 & Not significant & Homo \\
\hline Forced Vital capacity & $\mathrm{L} / \mathrm{min}$ & 0.641 & 0.892 & Not significant & Homo \\
\hline $\begin{array}{l}\text { Forced expiratory } \\
\text { volume }(F E V \&)\end{array}$ & $\mathrm{L} / \mathrm{min}$ & 1.982 & 0.762 & Not significant & Homo \\
\hline Vital capacity $(V C)$ & $\mathrm{L} / \mathrm{min}$ & 1.198 & 0.832 & Not significant & Homo \\
\hline Achievement & $\sec$ & 1.762 & 0.879 & Not significant & Homo \\
\hline
\end{tabular}

The mean (m), standard deviation (sd) and t value for the tests results of the two groups are shown in table 3.

The results are for the test before the training (primary test) which shows the level is significant at significance where the error is less than 0.05 .

At this level of 0.05 and degree of freedom of 12, the two tables (2 \&3) are showing clearly the random differences between the monitored group and experimental group. This means, there is high homogeneity and equivalence between the two groups. 
Table 3. Statistical calculations.

\begin{tabular}{|l|l|l|l|l|l|l|l|l|}
\hline \multirow{2}{*}{ Variables } & \multirow{2}{*}{ Unit } & \multicolumn{2}{l}{ Monitored group } & \multicolumn{2}{|l|}{ Experimental Group } & \multirow{2}{*}{ value } & Error & $\begin{array}{l}\text { Significance of } \\
\text { differences }\end{array}$ \\
\hline Age & year & 16.82 & 1.67 & 16.23 & 1.82 & 1.110 & 0.355 & random \\
\hline Training age & year & 5.113 & 0.897 & 4.998 & 0.762 & 1.698 & 0.061 & random \\
\hline Tall & $\mathrm{cm}$ & 69.10 & 2.861 & 70.210 & 1.54 & 0.567 & 0.442 & random \\
\hline Weight & $\mathrm{kg}$ & 178.59 & 9.186 & 177.23 & 9.332 & 0.431 & 0.241 & random \\
\hline $\begin{array}{l}\text { Forced } \\
\text { capacity }\end{array}$ & L/min & 3.64 & 0.640 & 3.535 & 0.347 & 0.542 & 0.431 & random \\
\hline $\begin{array}{l}\text { Forced expiratory } \\
\text { volume }(F E V \&)\end{array}$ & L/min & 3.566 & 0.397 & 3.387 & 0.382 & 0.087 & 0.331 & random \\
\hline $\begin{array}{l}\text { Maximum } \\
\text { Voluntary } \\
\text { Ventilation }\end{array}$ & L/min & 102.9 & 12.201 & 100.9 & 5.68 & 0.783 & 0.398 & random \\
\hline Achievement & $\mathrm{sec}$ & 1.590 & 0.932 & 1.580 & 0.897 & 0.541 & 0.221 & random \\
\hline
\end{tabular}

Vicatest Spirometer device made by (Hillige Company-Germany) was used to measure lungs functional variables with a measurement achievement time of $80 \mathrm{~m}$ :

Forced Vital Capacity

Forced Expiratory Volume in one Second 3- Maximum Voluntary Ventilation

\section{Procedure}

We chose 5 samples for this experiment and we decide to apply the experimental regulations we follow in one day, one hour in physical science and sport faculty stadium/ Baghdad university. We were investigating and examining the stability and validity of the devices and tools used in this study. The time taken to complete each experiment was determined and any other issues were also defined. This kind of study needs to define few important factors which are important to adopt the results for analysis stage.

Virtual honesty factor for all tests have to approved and valid for lungs functional variable by an experts and specialist scientists in this field.

Stability factor was extracted by repeating the exploration experiment after 3 days from the first test.

Spearman's rank correlation coefficient calculated for the first and the second test as shown in table (2). At 3 degree of freedom and 0.05 level of significance, the T calculated value is more than the table value of 2.11 and this confirmed that the test is highly stabile.

Table 4. The stability factor and objectivity test results.

\begin{tabular}{|l|l|l|l|l|l|l|l|}
\hline Test & Unit & Stability & T value & $\begin{array}{l}\text { Statistical } \\
\text { significance }\end{array}$ & Objectivity & T value & $\begin{array}{l}\text { Statistical } \\
\text { significance }\end{array}$ \\
\hline Forced Vital capacity & L/min & 0.78 & 3.321 & significant & 0.921 & 4.431 & significant \\
\hline $\begin{array}{l}\text { Forced expiratory } \\
\text { volume }(F E V \&)\end{array}$ & 0.88 & 3.798 & significant & 0.889 & 3.223 & significant \\
\hline $\begin{array}{l}\text { Maximum Voluntary } \\
\text { Ventilation }\end{array}$ & L/min & 0.9 & 4.321 & significant & 0.879 & 3.764 & significant \\
\hline Achievement & L/min & 0.89 & 2.522 & significant & 0.882 & 3.903 & significant \\
\hline
\end{tabular}


Correlation results of two judgments was determined to define the objectivity, which Spearman's rank correlation coefficient confirmed that it is high, as shown in Table 4.

\section{Measures}

The following procedures were implemented in the training units of the study and it was taken a high consideration:

- Trainings were in special preparation stage.

- Various types of training were used.

- 3 training units every week (Saturday, Monday and Wednesday) and for 8 weeks.

- Trainings are in relation to Lactate threshold.

- Strength of Lactate threshold training exercise is in the range of $80 \%-90 \%$ from runner maximum limit ability based on exploratory experimental results of each runner.

- Exercise strength determined from the result of heart rate stress exercise which is found to be reasonable to keep it within the range of $(175-185 \mathrm{bpm})$.

- The training exercise took place at the binging of the training unit.

After achieving all exercises and training units within the planning time period, the physical tests were taken place in the same faculty stadium and by applying the same boundary conditions as used before. All collecting data was analysis and treated by using SPSS statistical package.

\section{DISCUSSION}

\section{Lungs functioning variables}

To have a good idea about lungs variables and to understand the difference between primary and final tests for the two groups, collected data inserts in table 5,6 and 7, to show clearly the significance of the results. However, table 5 shows that the Sig value for the final test and for all variables is less than 0.05 , which means significant

Table 5. The mean and standard deviation of lungs functional variables (LFVs) for experimental group.

\begin{tabular}{|c|c|c|c|c|c|c|}
\hline LFVs & & $-m$ & $\pm s d$ & T value & Sig & $\begin{array}{l}\text { Significance } \\
\text { differences }\end{array}$ \\
\hline \multirow{2}{*}{$F V C(L)$} & Primary & 3.642 & 0.642 & \multirow{2}{*}{-2.793} & \multirow{2}{*}{0.00} & \multirow{2}{*}{ significant } \\
\hline & Final & 4.398 & 0.712 & & & \\
\hline \multirow{2}{*}{$F E V \&(L)$} & Primary & 3.596 & 0.397 & \multirow{2}{*}{2.561} & \multirow{2}{*}{0.021} & \multirow{2}{*}{ significant } \\
\hline & Final & 3.787 & 1.397 & & & \\
\hline \multirow{2}{*}{$M V V(L / m i n)$} & Primary & 102.8 & 12.201 & \multirow{2}{*}{-4.67} & \multirow{2}{*}{0.011} & \multirow{2}{*}{ significant } \\
\hline & Final & 108.6 & 12.71 & & & \\
\hline \multirow{2}{*}{$800 \mathrm{~m}$ sprinting acheivement } & Primary & 1.580 & 0.897 & \multirow{2}{*}{-7.432} & \multirow{2}{*}{0.00} & \multirow{2}{*}{ significant } \\
\hline & Final & 1.470 & 0.763 & & & \\
\hline
\end{tabular}

Same as showing in table 5 , table 6 shows the results for the monitored group and the result is demonstrated a significant result for the final test as it is less than 0.05 . 
Table 6. The mean and standard deviation of lungs functional variables (LFVs) for monitored group.

\begin{tabular}{|c|c|c|c|c|c|c|}
\hline \multicolumn{2}{|l|}{ LFVs } & $-m$ & $\pm s d$ & T value & Sig & $\begin{array}{l}\text { Significance } \\
\text { differences }\end{array}$ \\
\hline \multirow{2}{*}{$F V C(L)$} & Primary & 3.64 & 0.542 & \multirow{2}{*}{3.043} & \multirow{2}{*}{0.043} & \multirow{2}{*}{ significant } \\
\hline & Final & 3.788 & 0.812 & & & \\
\hline \multirow{2}{*}{$F E V \&(L)$} & Primary & 3.566 & 0.554 & \multirow{2}{*}{-4.675} & \multirow{2}{*}{0.034} & \multirow{2}{*}{ significant } \\
\hline & Final & 3.599 & 1.623 & & & \\
\hline \multirow{2}{*}{$M V V(L / \mathrm{min})$} & Primary & 102.9 & 11.62 & \multirow{2}{*}{-3.907} & \multirow{2}{*}{0.022} & \multirow{2}{*}{ significant } \\
\hline & Final & 103.4 & 11.67 & & & \\
\hline \multirow{2}{*}{$800 \mathrm{~m}$ sprinting acheivement } & Primary & 1.590 & 0.932 & \multirow{2}{*}{-2.998} & \multirow{2}{*}{0.0321} & \multirow{2}{*}{ significant } \\
\hline & Final & 1.580 & 0.892 & & & \\
\hline
\end{tabular}

Table 7 shows the differences between table 5 and 6 , and therefore, the significance result go to the experimental group Sig results is less than 0.05 .

Table 7. The mean and standard deviation of lungs functional variables (LFVs) for the two groups.

\begin{tabular}{|c|c|c|c|c|c|c|c|c|}
\hline \multirow{2}{*}{ LFVs } & \multirow{2}{*}{ Unit } & \multicolumn{2}{|c|}{$\begin{array}{l}\text { Experimental } \\
\text { Group }\end{array}$} & \multicolumn{2}{|c|}{ Monitored Group } & \multirow{2}{*}{ T value } & \multirow{2}{*}{ Sig } & \multirow{2}{*}{$\begin{array}{l}\text { Significance } \\
\text { differences }\end{array}$} \\
\hline & & $m$ & $s d$ & $\mathrm{~m}$ & $s d$ & & & \\
\hline$F V C$ & $\mathrm{~L}$ & 4.398 & 0.712 & 3.788 & 0.812 & 8.901 & 0.000 & significant \\
\hline FEV\& & $\mathrm{L}$ & 3.787 & 1.397 & 3.599 & 1.623 & 8.891 & 0.002 & significant \\
\hline$M V V$ & $L / \mathrm{min}$ & 108.6 & 12.71 & 103.4 & 11.672 & 11.432 & 0.032 & significant \\
\hline \begin{tabular}{|l|}
$800 \mathrm{~m}$ sprintin \\
acheivement
\end{tabular} & ec & 1.470 & 0.763 & 1.580 & 0.892 & 6.783 & 0.043 & significant \\
\hline
\end{tabular}

As per of the results in the previous tables, which obviously shows the significant evidence to the advantage of the final test for both of the groups. Confirming that the LTT program is strongly improving LFVs and runners' abilities consequently.

The powerful effect of the physiological skills in enhancing and expanding LFVs is noticeable. The enhancement in LFVs is a natural result of lungs vital capacity expansion, powerful strength of breathing muscles, the enlargement of breathing air volume and gases exchange with blood after 12 weeks of LTT based on 3 training units a week.

Mohammed Osman confirmed that the future of sport training is depend directly on the energy systems. The most important principle in field training activity is the compromise between the athletics special training skills with energy system functionality in real time of champagne activity to achieve the highest and possible target.

Mohammed Redah indicated his observations about athletics and different types of sport activity and the needs of each activity to different amount of energy and muscle effort. Therefore, improving sport achievement level needs so much support to training program and planning to gain higher efficiency in energy system and muscle effort. Ibrahim Alskar et al, consistent with this aspect as they mentioned that the LTT is improving blood circulatory and respiratory systems which they work together to circulate blood and oxygen throughout the body. However, endurance is correlated to heart ability, blood circulated system efficiency and chemical muscle reaction. 
To focus on the significance differences in LFVs mentioned previously, we are referring this fact to $F V C$, $F E V \&$ which is relating to the increase in lungs air volume (inhalation and exhalation) as a result of LTT. Abu Alula described positive the relation between sport training, the strength of muscle breathing, lungs vital capacity air breathing volume.

The organized training leads to adaptations in the respiratory system and due to $F V C, F E V \&$ and Volume and breathing capacities. Astrand in 1979 studied this principle and his research conclusions of students' program training after completion is same.

Another research conclusion was submitted by Almandalaui et al, about period training. This type of training leads to increase runner ability to speed up under such high oxygen availability and improve blood circulation and lungs functioning.

Mohammed Osman research was concentrating on high strength period training method. He proved this method and such method will improve blood circulation and lungs functioning because of lungs and heart vital capacity as well as the blood are getting richest in oxygen. High operational physical strength and body power are increased subsequently.

Operational and organizational training is for sure will lead to make changes in body tissues and cells. The variations after aerobic training give more oxygen to the muscles and having more power. Myoglobin (oxygenbinding protein) and Mitochondrion will increase in body blood followed by an enhancement Glycogen muscle storages and highly active biological catalysts Enzymes. Muscles are getting more able to burn fat and divert it into consumption energy and in this case the objectives are strongly accomplished.

\section{CONCLUSIONS}

This study confirmed the importance of LTT which the Experimental group went through, and the runners shows a good development in $800 \mathrm{~m}$ race. It is also increased LFVs to much better level (significant) due to the gained results of $F V C, F E V \&$ and $M V V$.

The researchers recommended few points for any future training in this manner:

- It is so important to apply LTT in training unit of $800 \mathrm{~m}$ Olympic sprinting.

- Athletics' coaches should use the functional measurements to understand the operation of body organs specially LFVs.

- Apply the same principles to study another type of sprinting athletics.

\section{REFERENCES}

Abu Alula A., Sport training physiology, Addition 1, Cairo, Dar Alfeker Alarabi, 2003.

Astrand, P.O and Rodahl, K, Text book of work physiology, McGraw-Hill Book Co, New York, 1979.

Ibrahim S., Abdulrahman A. Z and Ahmed S. H., Encyclopedia of the physiology of track competitions, Addition 1, Alketab Centre for publication, Cairo, 1998.

Mhammed O., Encyclopaedia of athletics technic-training-arbitration, Kuwait, Dar Alkalam, 1990.

Mohammed. R. I., Practical application (Arena) for theories and methods of sports training, Addition, Baghdad, National Library, 2008.

William D. McArdle, Frank I. Katch and Victor L. Katch, Exercise physiology, Lea \& Febiger publications, 2nd edition, 1986. 


\section{(c) (i) (3)}

This work is licensed under a Attribution-NonCommercial-NoDerivatives 4.0 International (CC BY-NC-ND 4.0). 